\title{
PENERAPAN TEORI SUPERIMPOSITION METHODS BERNARD TSCHUMI PADA PENGOLAHAN SAMPAH DAN SARANA EDUKASINYA
}

\author{
Adriel Gandhi ${ }^{1)}$, Sidhi Wiguna Teh ${ }^{2)}$ \\ 1)Program Studi S1 Arsitektur, Fakultas Teknik, Universitas Tarumanagara, awidjaa@gmail.com \\ 2) Program Studi S1 Arsitektur, Fakultas Teknik, Universitas Tarumanagara, sidhi@ft.untar.ac.id
}

\begin{abstract}
Abstrak
Indonesia merupakan negara penghasil sampah terbanyak di dunia setelah Cina, hal ini mempengaruhi ekosistem laut dan lingkungan hidup manusia itu sendiri. Jakarta merupakan salah satu penyumbang sampah terbanyak, oleh karena itu dibutuhkan upaya untuk mengatasi masalah sampah ini yang dapat dimulai dari suatu daerah yaitu Jakarta Utara. Jakarta Utara merupakan muara dari 13 sungai di Jakarta yang menjadikan daerah ini salah satu penghasil sampah terbanyak di Jakarta. Fasilitas pengolahan sampah di Jakarta Utara merupakan fasilitas yang memperkenalkan proses pengolahan sampah di Jakarta dengan berwawasan lingkungan kepada masyarakat. Fasilitas ini terletak di kawasan Kecamatan Penjaringan, dimana pada kawasan ini akan dibangun tempat pengolahan sampah untuk mengatasi permasalahan sampah sekitar dan diharapkan dapat digunakan warga sebagai sarana edukasi. Fasilitas ini dapat menjadi tujuan wisata bagi masyarakat dalam mengenal jenis-jenis, proses dan hasil pengolahan sampah. Fasilitas ini juga akan mengenalkan dampak dan informasi tentang sampah serta masyarakat dapat terjun langsung dalam proses pengolahan sampah. Selain itu, fasilitas ini dilengkapi dengan fasilitas pendukung, yaitu area eksibisi dan toko souvenir. Pendekatan perancangan arsitektur menggunakan superimposition methods Bernard Tschumi yang dipilih dengan tujuan untuk mengatasi masalah perancangan. Proyek ini diharapkan dapat mengatasi permasalahan sampah yang ada di Indonesia dan menghapus nama Indonesia dari daftar penghasil sampah terbanyak di dunia yang dimulai dari suatu daerah yaitu Jakarta Utara.
\end{abstract}

Kata Kunci: Edukasi; Indonesia; Jakarta; Pengolahan sampah; sampah

\begin{abstract}
Indonesia is the largest waste-producing country in the world after China, this affects marine ecosystems and the human environment itself. Jakarta is one of the largest contributors of waste, therefore efforts are needed to overcome this waste problem which can be started from an area, namely North Jakarta. North Jakarta is the estuary of 13 rivers in Jakarta which makes this area one of the largest waste producers in Jakarta. The waste processing facility in North Jakarta is a facility that introduces the waste processing process in Jakarta with an environmental perspective to the public. This facility is located in the Penjaringan sub-district, where in this area a waste processing site will be built to overcome the surrounding waste problem and is expected to be used by residents as a means of education. This facility can be a tourist destination for the community in recognizing the types, processes and results of waste processing. This facility will also introduce the impact and information about waste and the community can be directly involved in the waste processing process. In addition, this facility is equipped with supporting facilities, namely an exhibition area and a souvenir shop. The architectural design approach uses Bernard Tschumi's superimposition methods which were chosen with the aim of overcoming design problems. This project is expected to be able to overcome the waste problem that exists in Indonesia and remove the name of Indonesia from the list of the largest waste producers in the world starting from an area, namely North Jakarta.
\end{abstract}

Keywords: education; garbage; Indonesia; Jakarta; Waste processing 


\section{PENDAHULUAN}

\section{Latar Belakang}

Jumlah produksi sampah plastik global sejak 1950 hingga 2015 cenderung selalu menunjukkan peningkatan. Pada 1950, produksi sampah dunia ada di angka 2 juta ton per tahun. Sementara 65 tahun setelah itu, pada 2015 produksi sampah sudah ada di angka 381 juta ton per tahun. Angka ini meningkat lebih dari 190 kali lipat, dengan rata-rata peningkatan sebesar 5,8 ton per tahun. Sampah plastik selalu menjadi masalah utama dalam pencemaran lingkungan baik pencemaran tanah maupun laut, dan Indonesia merupakan salah satu penghasil sampah terbesar di dunia. (Kompas, 2018). Permasalahan tentang sampah di Indonesia memerlukan solusi yang lebih dari sekedar membuang sampah pada tempatnya. Indonesia saat ini menempati posisi kedua sebagai negara penyumbang sampah terbesar di dunia setelah Cina (Kompas, 2016).

Jakarta merupakan salah satu kota penghasil sampah terbanyak di Indonesia. Pada 2020, 7.424 ton sampah masuk ke Bantar Gebang tiap harinya (Republika, 2021). oleh karna itu sampah-sampah ini harus ditanggulangi dan diolah kembali. Masih banyak sampah hanya dibiarkan menumpuk pada TPATPA di daerah yang berujung pada over capacity, karena masih kurangnya tempat pengolahan sampah di Jakarta. Kurangnya bangunan pengolahan sampah di Jakarta menyebabkan banyaknya sampahsampah yang menumpuk di banyak tempat sehingga menyebabkan kawasan kota Jakarta menjadi kumuh dan tidak sehat. Berdasarkan data statistik Jakarta, Jakarta bagian Utara merupakan bagian daerah Jakarta dengan tingkat produksi sampah yang cukup banyak, oleh karena itu hal ini harus di tanggulangi demi kesehatan dan kebersihan lingkungan.

Sampah untuk kehidupan merupakan tema utama untuk proyek pengolahan sampah dengan sarana edukasi yang akan dirancang untuk menanggulangi permasalahan penumpukan sampah yang terjadi di Jakarta Utara. Dengan begitu Selain menanggulangi penumpukan sampah tersebut, proyek ini juga dapat memproses kembali sampah sampah tersebut sehingga menghasilkan manfaat lain yang dapat digunakan kembali Selain itu juga proyek ini dirancang dengan sarana edukasi yang dapat memberikan ilmu kepada masyarakat. IImu yang diberikan dengan tujuan mengedukasi masyarakat tentang cara pengolahan sampah agar dapat dimanfaatkan kembali.

\section{Rumusan Permasalahan}

a. Bagaimana mengatasi permasalahan sampah yang dihasilkan Jakarta?

b. Bagaimana cara mengajak masyarakat untuk mengatasi permasalahan sampah tersebut?

c. Bagaimana desain arsitektur yang baik agar dapat menarik dan menyadarkan masyarakat untuk ikut serta mengatasi masalah sampah di Indonesia?

\section{Tujuan}

a. Menciptakan program untuk mengolah produksi sampah berlebih yang dihasilkan kota Jakarta

b. Mengurangi penumpukan sampah yang terjadi di indonesia

c. Mengedukasi masyarakat tentang cara pengolahan sampah

d. Menciptakan lingkungan hidup yang bersih dan sehat dengan mengolah sampah untuk bisa dimanfaatkan Kembali

\section{KAJIAN LITERATUR}

\section{Ekologi}

Ekologi menurut KBBI adalah ilmu tentang hubungan timbal balik antara makhluk hidup dan (kondisi) alam sekitarnya (lingkungannya)

Ekologi menurut para ahli:

- Menurut Ernst Heackel (1968 dalam Ramli, 1989), ekologi adalah ilmu yang mempelajari hubungan timbal balik antara organisme dengan lingkungannya.

- Kreb (1972 dalam Ramli, 1989) mengemukakan bahwa ekologi merupakan ilmu yang mempelajari interaksi-interaksi penyebaran dan jumlah dari organisme. 
- Pianka (1988 dalam Smith, 1990) menyatakan bahwa ekologi adalah ilmu yang mempelajari hubungan antara organisme dan seluruh faktor fisik dan biologi yang mempengaruhi dan di pengaruhinya.

\section{Sampah}

Definisi sampah menurut beberapa ahli:

- Menurut Kodoatic (2003), sampah merupakan limbah padat atau setengah padat dari hasil kegiatan manusia, hewan atau tumbuhan atau kegiataan perkotaan.

- Menurut Azwar (1990) menerangkan dalam bukunya bahwa sampah adalah segala sesuatu yang sudah tidak dipakai, dipergunakan, disenangi sehingga harus dibuang.

- Menurut SK SNI T-13-1990 F, sampah adalah limbah padat baik yang terdiri dari zat organik maupun anorganik yang di kelola dengan komponen-komponen subsistem yang saling mendukung, berinteraksi dan berhubungan satu sama lain.

- Menurut Undang-Undang RI Nomor 18 Tahun 2008 tentang Pengelolaan Sampah, sampah adalah sisa kegiatan sehari-hari manusia dan atau proses alam yang berbentuk padat. Kemudian yang dimaksud dengan sampah spesifik adalah sampah yang karena sifat, konsentrasi, dan atau volumenya memerlukan pengelolaan khusus. Pengelolaan sampah dimaksudkan adalah kegiatan yang sistematis, menyeluruh, dan berkesinambungan 12 yang meliputi pengurangan dan penanganan sampah.

\section{Permasalahan Sampah di Indonesia}

Banjir semakin lama semakin menjadi di banyak kota di Indonesia. Demikian juga dengan suhu kota yang terus meningkat. Penyebab banjir mulai dari kurangnya daerah resapan air, hingga masalah sampah. Sayangnya belum banyak pihak yang mengelola masalah sampah ini dengan baik. Pengelolaan sampah yang buruk di kota kota Indonesia mulai dari individu yang tidak membuang sampah atau limbah pada wadah yang seharusnya, sistem pendistribusian yang tidak efisien, dan kurangnya sistem pengolahan kembali. Salah satu penghasil sampah tertinggi di Indonesia adalah kota Jakarta.

Perkembangan penduduk sedikit banyak telah membawa banyak dampak negatif bagi masyarakat. Salah satu permasalahan klasik yang dihadapi oleh masyarakat kota Jakarta adalah penumpukan sampah. Hal ini dikarenakan pertumbuhan populasi yang cukup tinggi dan juga diikuti oleh aktifitasnya yang menghasilkan sampah. Tempat pembuangan sampah Bantar Gebang merupakan tempat pembuangan sampah akhir dari sampah seluruh Jakarta. Pada 2020, 7.424 ton sampah masuk ke Bantar Gebang tiap harinya (Republika, 2021). Tempat pembuangan sampah ini sudah hampir mengalami overcapacity.

Jenis-Jenis Sampah (Bulelengkab, 2019)

\section{Sampah Padat (Anorganik)}

Sampah anorganik adalah sampah yang terdiri atas bahan-bahan anorganik. Contoh bahan-bahan anorganik adalah bahan logam, plastik, kaca, karet, dan kaleng. Sifat sampah anorganik adalah tahan lama dan sukar membusuk. Sampah ini tidak mudah diuraikan oleh mikroorganisme tanah. Apabila dibuang sembarangan, sampah anorganik dapat menimbulkan pencemaran tanah.

Contoh dari sampah anorganik adalah plastik, botol / kaleng minuman, kresek, ban bekas, besi, kaca, kabel, barang elektronik, bohlam lampu dan plastik. Memang sampah anorganik sulit terurai tetapi dapat anda manfaatkan kembali, jangan sampai dibiarkan begitu saja.

\section{Sampah Basah (Organik)}

Sampah organik adalah sampah yang terdiri atas bahan-bahan organik. Sifat sampah organik adalah tidak tahan lama dan cepat membusuk. Biasanya sampah jenis ini berasal dari makhluk hidup. Contohnya adalah sayur-sayuran, buah-buah yang membusuk, sisa nasi, daun, dan sebagainya. 
Sampah organik mudah diuraikan mikroorganisme tanah. Hanya saja jenis sampah akan menimbulkan bau kurang sedap jika tidak dikelola dengan baik.

\section{Jenis - Jenis Sampah Organik :}

Berdasarkan jenisnya sampah organik dapat digolongkan menjadi 2 antara lain sampah organik basah dan kering. (Bulelengkab, 2019)

- Sampah Organik Basah

- Sampah organik basah adalah sampah organik yang banyak mengadung air. Sampah organik basah contohnya adalah sisa sayur, kulit pisang, buah yang busuk, kulit bawang dan sejenisnya.

- Inilah yang saya katakan bahwa sampah organik dapat menimbulkan bau tidak sedap sebab kandungan air tinggi yang menyebabkan sampah jenis ini cepat membusuk.

- Sampah Organik Kering

- Sampah organik kering adalah sampah organik yang sedikit mengandung air. Contoh sampah organik misalnya kayu, ranting pohon, kayu dan daun - daun kering. Kebanyakan sampah organik sulit diolah kembali jadi lebih sering dibakar untuk memusnahkannya.

- Contoh dari dari sampah organik adalah nasi, kulit buah, buah dan sayuran busuk, ampas teh / kopi, bangkai hewan, dan kotoran hewan / manusia

\section{Sumber Sampah}

Sampah dapat bersumber dari berbagai aktivitas seperti rumah tangga, sampah pertanian, sampah sisa bangunan, sampah dari perdagangan dan perkantoran, serta sampah dari industri. Dengan kata lain sambah bersumber dari kegiatan yang di lakukan manusia. Seiring berjalannya waktu populasi penduduk bertambah dan menyebabkan kegiatan manusia meningkat mengikuti pertumbuhan populasi tersebut, oleh karena itu produksi sampah juga meningkat pesat.

\section{Cara Pengolahan Sampah (Palangkaraya, 2021)}

\section{Kompos}

Sampah organik yang bisa diubah menjadi kompos:

- Sampah sisa makanan dari sayur-sayuran, kulit buah, dan daging

- Bumbu dapur yang sudah kedaluwarsa.

- Potongan kayu.

- Daun-daunan.

- Potongan rambut.

- Bulu hewan yang rontok.

- Debu belakang lemari es.

- Kotoran hewan peliharaan.

- Kertas bekas dan sampah tisu.

Pengolahan sampah untuk menjadi pupuk kompos dengan mencampurkan tanah ke sampah organik yang telah disiapkan, setelah itu dimasukan ke dalam alat pengolahan kompos untuk diproses menjadi pupuk kompos.

\section{Plastik}

Pengolahan sampah plastik untuk menjadi biji plastik dilakukan dengan mengguanakan alat pengolah plastic dengan memanaskannya dan membentuknya kembali menjadi biji plastik.

\section{Energi Listrik}

Langkah-langkah pengolahan menjadi energi listrik :

- Sampah dibakar sehingga menghasilkan panas (proses konversi thermal)

- Panas dari hasil pembakaran dimanfaatkan untuk mengubah air menjadi uap dengan bantuan boiler

- Uap bertekanan tinggi digunakan untuk memutar bilah turbin 
- Turbin dihubungkan ke generator dengan bantuan poros

- Generator menghasilkan listrik dan listrik dialirkan ke bangunan

Langkah-Langkah Pengolahan Sampah di Tempat Pengolahan Sampah (jatengprov, 2018)

1. Pre-processing atau kegiatan sebelum pemrosesan, meliputi

2. Penimbangan, untuk mengetahui jumlah sampah yang masuk.

3. Penerimaan dan penyimpanan, untuk menentukan area penimbunan sampah yang belum diolah.

4. Pengolahan sampah secara fisik

5. Proses pencacahan, yang bertujuan untuk memperkecil ukuran sampah sebelum diolah.

6. Proses pemilahan berdasarkan ukuran dan berat jenis, yang berlaku untuk sampah plastik.

7. Proses pemilahan berdasarkan sifat kemagnetan, umumnya dilakukan untuk pemilahan sampah logam.

8. Pengolahan sampah secara biologi

Proses ini memanfaatkan mikroorganisme dan dipilih karena dianggap lebih berwawasan lingkungan. Kegiatan pengolahan sampah dapat berupa pengomposan dan produksi gas bio.

9. Pengolahan sampah secara kimia

Proses ini bertujuan untuk mengurangi volume dan daya cemar sampah dengan memanfaatkan suhu tinggi. Pengolahan sampah dapat berupa:

- Proses untuk menghasilkan energi listrik, yaitu pirolisis (pembakaran sampah suhu tinggi tanpa udara), gasifikasi (pembakaran sampah dengan sedikit udara), dan proses insinerasi (pembakaran sampah biasa).

- Proses untuk menghasilkan biji plastik, yaitu dengan melelehkan sampah plastik dan mencetaknya kembali dalam ukuran tertentu.

Manfaat Sampah (bulelengkab, 2019)

Manfaat sampah organik

- Sampah Organik Untuk Kompos / Pupuk Organik

- Untuk Tambahan Pakan Ternak

- Sampah organik dapat diubah menjadi biogas dan listrik

\section{Manfaat Sampah Anorganik}

Membuat kerajinan dari sampah / limbah tersebut. Misalnya sampah plastik dapat dibuat tas, taplak meja makan, pernak pernik. Selain itu juga dapat dipanaskan untuk dibuat biji plastic untuk dijual lagi.

\section{Dampak Sampah Terhadap Lingkungan}

Dampak buruk lingkungan kotor serta polusi sampah terhadap lingkungan salah satunya adalah pencemaran air. Pencemaran air dapat terjadi ketika sampah dibuang ke sungai. Selain mencemari air sungai, pembuangan limbah atau sampah juga dapat menghambat proses air tanah dan merupakan sebuah kabar buruk mengingat air tanah sangatlah penting bagi manusia. Selain mencemari sungai dan menghambat proses air tanah, sampah juga dapat mencemari tanah dan menjadikannya tidak sehat.

\section{Dampak Sampah Terhadap Manusia}

Polusi sampah dan lingkungan yang kotor juga dapat membawa dampak buruk pada manusia yang tinggal di lingkungan tertentu. Sebagai contoh, polusi sampah diketahui dapat mengakibatkan peningkatan berbagai macam penyakit infeksi saluran pencernaan, dan sebagainya. Hal ini disebabkan karena dengan adanya sampah yang menumpuk tanpa di buang ketempat yang selayaknya, binatang pembawa penyakit seperti lalat akan menjadi semakin banyak. 
Dampak lain yaitu terjadinya gangguan pernafasan. Hal ini bisa terjadi jika solusi yang digunakan untuk mengelola sampah yang menggunung adalah dengan membakarnya. Sampah yang dibakar, terutama sampah anorganik, dapat membahayakan lingkungan dan kesehatan manusia yang hidup di dalamnya. Pengelolaan sampah yang baik menjadi salah satu kunci penting dalam menjaga kesehatan lingkungan mengingat pengelolaan sampah yang buruk akan berakibat pada kotornya lingkungan serta polusi sampah yang tentu saja membawa banyak dampak buruk bagi manusia maupun lingkungan.

\section{Edukasi}

Edukasi atau disebut juga dengan pendidikan merupakan segala upaya yang direncanakan untuk mempengaruhi orang lain baik individu, kelompok, atau masyarakat sehingga mereka melakukan apa yang diharapkan oleh pelaku pendidikan (Notoatmodjo, 2003).

\section{Sarana dan Prasarana Pendidikan/ Edukasi}

- Sarana pendidikan diartikan sebagai alat untuk mencapai tujuan pendidikan, misalkan buku, tas, pulpen, komputer dan lain-lain.

- Prasarana pendidikan diartikan sebagai perangkat kelengkapan dasar yang secara tidak langsung menunjang pelaksanaan proses pendidikan misalnya, lokasi, bangunan, ruangan, dan lain-lain.

Pengertian lainnya, sarana pendidikan adalah semua perangkat peralatan, bahan dan perabot yang secara langsung digunakan dalam proses pendidikan sedangkan prasarana pendidikan adalah semua perangkat kelengkapan dasar yang secara tidak langsung menunjang pelaksanaan proses pendidikan. Jenis Sarana dan Prasarana Pendidikan / Edukasi

Alat pelajaran adalah sarana pendidikan yang digunakan secara langsung dalam proses pembelajaran, misalnya; buku, alat tulis, penggaris, alat dan bahan

Alat peraga adalah semua semua alat bantu proses pendidikan dan pengajaran yang dapat mempermudah dan memberikan pengertian kepada anak didik baik yang bersifat abstrak maupun konkret.

Media pembelajaran adalah sarana pendidikan yang digunakan sebagai perantara dalam pembelajaran. Media pembelajaran ini dibagi menjadi tiga jenis yaitu media audio, media visual dan media audio visual. Media audio seperti tape recorder, radio, lab, dan sebagainya. Media visual seperti poster, bagan, gambar, kartun, dan Media audio visual seperti film, vcd, dan sebagainya.

Jenis Edukasi (jambikota, 2021)

\section{Formal}

Proses pembelajaran ini umum diselenggarakan di sekolah dan ada peraturan yang berlaku serta harus ditaati ketika sedang mengikuti proses pembelajaran tersebut, lalu ada pihak terkait yang mengawasi proses pembelajaran di sekolah. Di Indonesia, pendidikan formal yang bisa ditempuh oleh setiap individu adalah mulai dari jenjang SD, SMP, dan SMA, hingga pendidikan tinggi.

\section{Non Formal}

Edukasi non formal biasanya banyak ditemukan di lingkungan tempat tinggal, contohnya terdapat tempat pendidikan baca tulis, lalu kursus-kursus yang banyak terdapat di lingkungan seperti kursus mobil, kursus musik, dan kursus-kursus lain.

\section{Informal}

Sedangkan edukasi informal merupakan jalur pendidikan yang terdapat di keluarga dan lingkungan sekitar rumah. Di dalam edukasi informal terdapat proses pembelajaran secara mandiri dan dilakukan atas dasar kesadaran serta rasa tanggung jawab yang dimiliki. 


\section{METODE}

"That there is no architecture without program, without action, without event, There is no fixed relationship between architectural form and the events that take place within it and There is no space without event." (Tschumi, 1994) menegaskan pandangan Tschumi bahwa arsitektur adalah tentang space (ruang), event (peristiwa) dan movement (pergerakan) yang disjunctive.

Terapat beberapa metode desain yan digunakan oleh Bernard Tschumi diantaranya:

\section{Cross Programming}

Menggunakan konfigurasi spasial tertentu untuk program yang sama sekali berbeda; misalnya bangunan gereja digunakan untuk tempat bowling. Menempatkan suatu konfigurasi spasial pada lokasi yang tidak berkaitan; misalnya museum diletakkan dalam bangunan struktur parkir, atau beauty parlour dalam sebuah gudang.

\section{Transprogramming}

Mengkombinasikan dua program yang sifat dan konfigurasi spasialnya berbeda; misalnya planetarium dikombinasikan dengan roller-coaster, perpustakaan dengan trek balap mobil .

\section{Disprogramming}

Mengkombinasikan dua program sedemikian rupa sehingga konfigurasi ruang program pertama mengkontaminasi program dan konfigurasi ruang kedua, misalnya supermarket dikombinasikan dengan perkantoran.

\section{Transformation}

Serangkaian perubahan bentuk suatu element.

\section{Superimposition}

Pertemuan element-element yang terpisah dan bertentangan yang berbeda dan berdiri sendiri yang mempengaruhi komposisi.

\section{Combination}

Penggabungan beberapa variabel/elemen yang berdiri sendiri.

\section{Disjunction}

Kondisi terputus, terpisah atau terpecah belah.

\section{Cinegram-montage}

Kombinasi secara beragam fragmen-fragmen kehidupan yang berdiri sendiri dengan cara pembalikan, perulangan, penggantian, dan penyisipan

Metode yang digunakan dalam proyek ini adalah Superimposition Methods, karena dinilai paling Cocok dengan kebutuhan dan program yang ada di proyek ini.

\section{DISKUSI DAN HASIL}

\section{Program}

Pemanfaatan kembali sampah dengan cara diolah kembali dan dibedakan menjadi 2 jenis yaitu sampah organik dan sampah anorganik. Sampah organik adalah sampah yang paling banyak ditemukan yang memiliki presentase jumlah mencapai $60 \%$ dari jumlah seluruh sampah yang ada, kemudian dilanjutkan dengan sampah anorganik 25\%, dan sampah lain-lain 15\%. Cara pengolahan sampah organik ini dengan cara dicampurkan dengan tanah untuk menjadi pupuk kompos. Proses ini terdiri dari pengendapan selama 20 hari dan juga penjemuran selama 10 hari, durasi pengolahan sampah organik ini sekitar 1 sampai 2 bulan. 
Pengolahan yang kedua adalah pengolahan sampah anorganik. Sampah anorganik diolah dengan cara dibakar, dan sisa panas pembakarannya dimanfaatkan untuk menjalankan generator listrik yang digunakan untuk sumber energi listrik bangunan. Sedangkan sampah lain-lain yang tidak dapat diolah dikumpulkan di bak penampungan sampah akhir untuk dibawa ke TPA Bantar Gebang. Dengan begitu kita dapat mengurangi jumlah sampah yang menumpuk di TPA Bantar Gebang yang sudah hampir mencapai overcapacity.

Program kedua yang ada di proyek ini merupakan edukasi tentang jenis-jenis pengolahan sampah dan juga cara pengolahannya. Jadi masyarakat mendapat wawasan tentang pengolahan sampah dengan cara yang menarik yaitu sistem eksibisi seperti pameran. Selain itu juga pengunjung juga dapat melihat proses pengolahan sampah secara langsung. Di sini juga terdapat workshop pengolahan sampah itu sendiri, agar pengunjung memiliki pengalaman tentang cara pengolahan sampah.

\section{Tapak}

Tapak terpilih ada di jalan Tuna Raya, RT.20/RW.17, Penjaringan, Kec. Penjaringan, Kota Jkt Utara, Daerah Khusus Ibukota Jakarta 14440. Kondisi di sekitar tapak merupakan bangunan - bangunan industri. Sesuai peruntukannya, tapak ini merupakan tapak industri yang memiliki beberapa titik penumpukan sampah di sekitar lokasi. Oleh karena itu tapak ini sangat cocok dengan program yang dimiliki proyek ini.

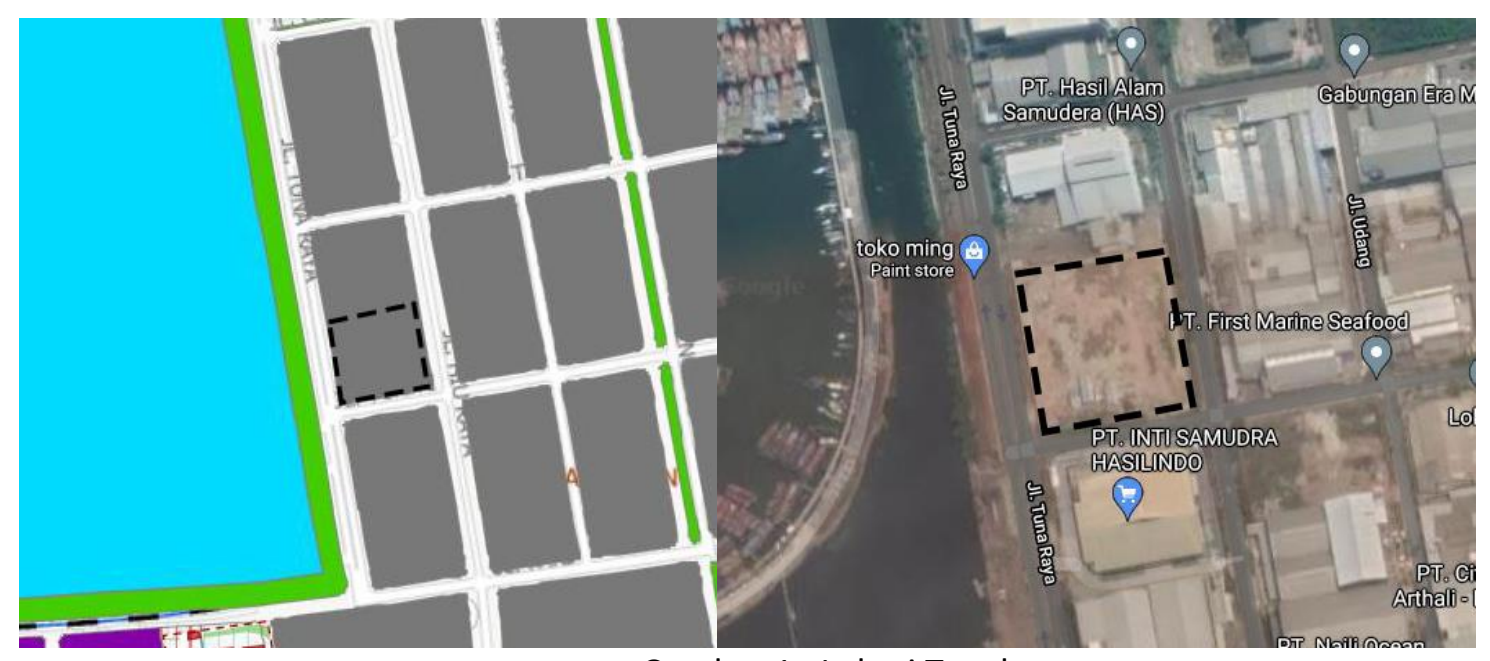

Gambar 1 : Lokasi Tapak

Sumber : Google Maps 2021, Jakarta Satu

\section{Konsep}

Desain proyek ini terinspirasi dari 3R yaitu Reduce, Reuse, Recycle yang identik dengan bentuk lingkaran yang akhirnya diaplikasikan ke dalam bangunan pengolahan. Setiap bagian lingkaran bangunan pada bangunan pengolahan memiliki fungsinya masing - masing, yang terdapat 3 bagian lingkaran yaitu 1. Bagian Drop Off sampah dan pemilahannya, 2. Bagian Pembakaran / pembakaran sampah, 3. Bagian pengomposan sampah.

Desain bangunan edukasi memiliki konsep yang berbeda yaitu Cycle of Life, yang merupakan perputaran kehidupan, dalam kasus ini yaitu kegiatan manusia yang menghasilkan sampah, sampah tersebut dimanfaatkan dan diolah kembali untuk aktifitas manusia dan untuk alam. 




Gambar 2. Konsep

Sumber : Penulis, 2021

Penggunaan material bangunan ini sebagian besar menggunakan concrete yang dipadukan dengan kayu sebagai aksen dan juga menggunakan tanaman rambat agar lebih terlihat asri. Untuk meminimalkan bau tak sedap yang dihasilkan program ini, menggunakan banyak pohon di daerah outdoor sebagai buffer terhadap bau.

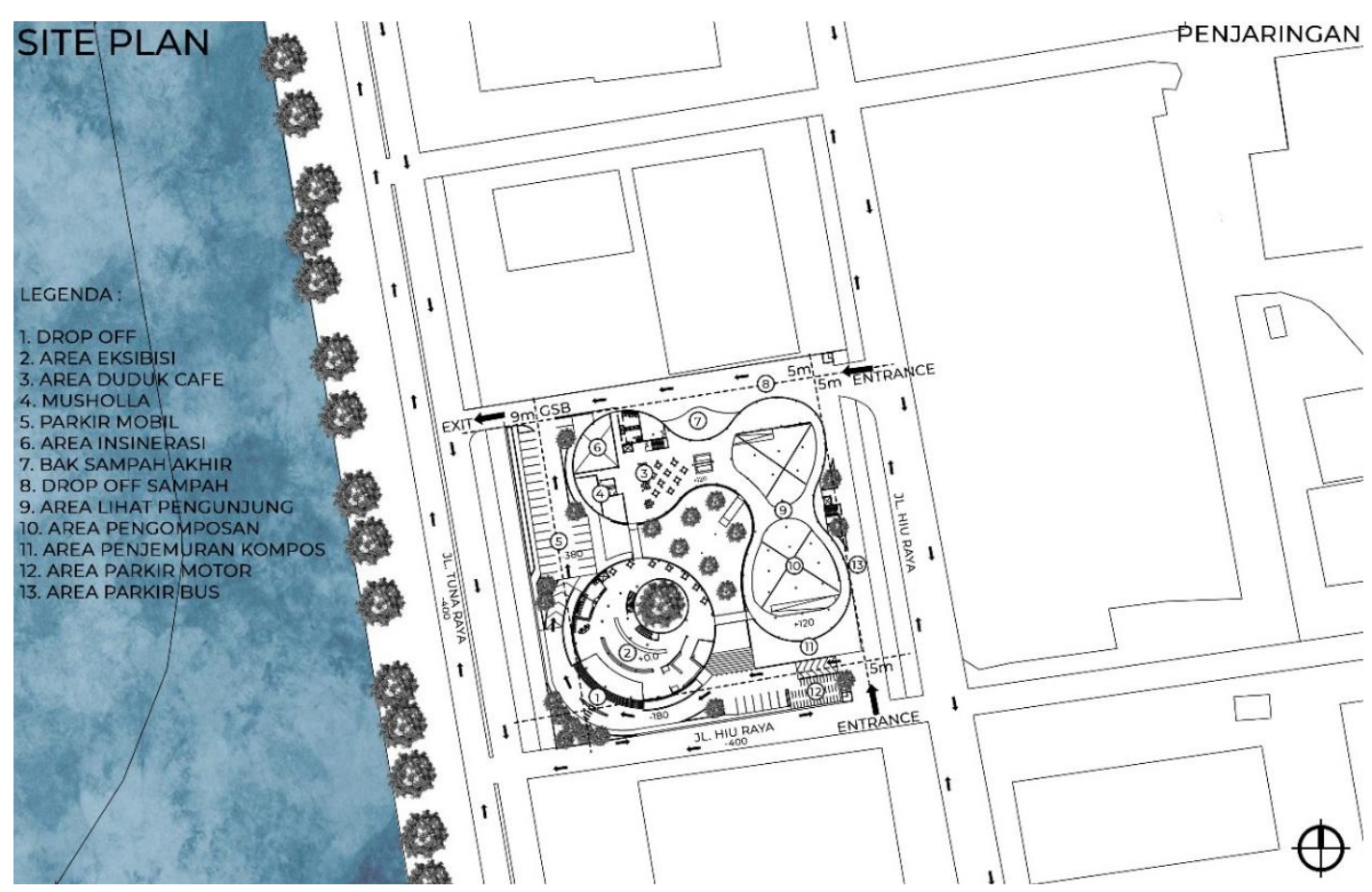

Gambar 3. Siteplan

Sumber : Penulis, 2021

\section{KESIMPULAN DAN SARAN}

\section{Kesimpulan}

Proyek ini mencoba menjawab permasalahan lingkungan yang terjadi di Jakarta, Khususnya di Jakarta Utara kawasan Penjaringan. Jakarta Utara merupakan daerah penghasil sampah yang cukup banyak dari seluruh Jakarta. Dengan adanya proyek ini diharapkan dapat mengolah sampah yang dihasilkan Jakarta Utara, serta mengurangi beban TPA Bantar Gebang dengan mengolah dan memanfaatkan sampah yang ada sehingga lingkungan Jakarta Utara menjadi lebih bersih dan sehat. Selain itu juga dapat mengurangi banjir yang terjadi di Jakarta yang salah satu penyebabnya adalah sampah. 
Dengan pengupayaan mengurangi sampah di daerah ini, diharapkan dapat mengurangi jumlah sampah yang dihasilkan Indonesia dan mengajak serta mengedukasi masyarakat indonesia untuk memahami dan ikut serta dalam pengolaan sampah tersebut sehingga masalah sampah yang terjadi di Indonesia dapat teratasi.

\section{Saran}

Untuk desain lanjutan harus lebih memperhatikan dan menyesuaikan desain dengan fungsi hubungan antar ruangan dan juga mencari cara yang lebih efektif dalam mengatasi bau yang ada di dalam proyek.

\section{REFERENSI}

Beritajakarta ( 2017, Oktober 09 ). Mesin Pengolahan Sampah di Ancol Menghasilkan 142 Ton Kompos. https://www.beritajakarta.id/read/50372/mesin-pengolah-sampah-di-ancol-hasilkan142-ton-kompos

Kompas ( 2019, Juli 04 ). 5 Kecanggihan ITF Sunter, Tempat Pengolahan Sampah yang Akan Dimiliki Jakarta. https://megapolitan.kompas.com/read/2019/07/04/10540471/5-kecanggihan-itfsunter-tempat-pengolahan-sampah-yang-akan-dimiliki?page=all

Kompas ( 2019, November 01 ). Jakarta Hasilkan 7.700 Ton Sampah per Hari. https://sains.kompas.com/read/2019/11/01/190700323/jakarta-hasilkan-7.700-ton-sampahper-

hari?page=all\#: :text=KOMPAS.com\%20\%E2\%80\%93\%20Pulau\%20Jawa\%20adalah,per\%20har ¡\%20mencapai\%207.700\%20ton.

Kompas ( 2018, November 21 ). Sampah Plastik Dunia dalam Angka https://internasional.kompas.com/read/2018/11/21/18465601/sampah-plastik-dunia-dalamangka?page=all

Sahwan, F. L. (2010). Tempat Pengolahan Sampah Terpadu (TPST) Urgensi dan Implementasinya. Pusat Teknologi LingkunganBadan Pengkajian dan Penerapan Teknologi

sehatq ( 2021, Januari 02 ). Mengenal Sampah Organik dan Non Organik: dari Sumber hingga Cara Mengolahnya.https://www.sehatq.com/artikel/mengenal-sampah-organik-dan-non-organikdari-sumber-hingga-cara-mengolahnya

Statistik Jakarta ( 2019 ). Rata-Rata Jumlah Sampah Yang Masuk Ke Tempat Pembuangan Akhir Bantar Gebang. http://statistik.jakarta.go.id/rata-rata-jumlah-sampah-yang-masuk-ke-tempatpembuangan-sampah-terakhir-tpst-bantar-gebang-2019/

Ukulele ( 2021, Maret 23 ). Edukasi Adalah. https://www.ukulele.co.nz/edukasi-adalah/

Wastuty, P. W. (2012). Hubungan Concept, Context, dan Content pada Karya Bernard Tschumi. 